\title{
IGNORING CHILDREN'S BEDTIME CRYING: THE POWER OF WESTERN-ORIENTED BELIEFS
}

\author{
MONIQUE MAUTE \\ University of Konstanz \\ SONJA PERREN \\ University of Konstanz and Thurgau University of Teacher Education
}

\begin{abstract}
Ignoring children's bedtime crying (ICBC) is an issue that polarizes parents as well as pediatricians. While most studies have focused on the effectiveness of sleep interventions, no study has yet questioned which parents use ICBC. Parents often find children's sleep difficulties to be very challenging, but factors such as the influence of Western approaches to infant care, stress, and sensitivity have not been analyzed in terms of ICBC. A sample of 586 parents completed a questionnaire to investigate the relationships between parental factors and the method of ICBC. Data were analyzed using structural equation modeling. Latent variables were used to measure parental stress (Parental Stress Scale; J.O. Berry \& W.H. Jones, 1995), sensitivity (Situation-Reaction-Questionnaire; Y. Hänggi, K. Schweinberger, N. Gugger, \& M. Perrez, 2010), Western-oriented parental beliefs (Rigidity), and children's temperament (Parenting Stress Index; H. Tröster \& R.R. Abidin). ICBC was used by 32.6\% ( $n=191)$ of parents in this study. Parents' Western-oriented beliefs predicted ICBC. Attitudes such as feeding a child on a time schedule and not carrying it out to prevent dependence were associated with letting the child cry to fall asleep. Low-sensitivity parents as well as parents of children with a difficult temperament used ICBC more frequently. Path analysis shows that parental stress did not predict ICBC. The results suggest that ICBC has become part of Western childrearing tradition.
\end{abstract}

Keywords: ignoring children's bedtime crying, controlled crying, infants sleep, cultural beliefs, parental stress and sensitivity

RESUMEN: El Ignorar el Llanto de los Niños a la Hora de Dormir (ICBC) es un asunto que polariza a padres así como a pediatras. Mientras que la mayoría de los estudios se enfoca en la efectividad de las intervenciones del dormir, ningún estudio se ha cuestionado todavía qué padres usan ICBC. Los padres a menudo hallan que las dificultades de dormir de los niños son muy desafiantes, pero los factores tales como la influencia de acercamientos occidentales al cuidado del infante, el estrés y la sensibilidad no se han analizado en términos de ICBC. Un grupo muestra de 586 padres completaron un cuestionario para investigar las relaciones entre los factores relacionados con los padres y el método de ICBC. La información se analizó usando un modelo de ecuación estructural. Se usaron variables latentes para medir el estrés de los padres (Escala de Estrés de los Padres), la sensibilidad (Cuestionario de Situación-Reacción), las creencias de los padres con orientación occidental (Rigidez) y el temperamento de los Niños (Índice de Estrés de la Crianza). El 32.6\% ( $\mathrm{n}=191)$ de los padres en este estudio usó ICBC. Las creencias de los padres con orientación occidental predijeron el ICBC. Actitudes tales como el dar de comer al niño siguiendo un horario y no hacerlo para prevenir la dependencia se asociaron con dejarle al niño llorar para que se durmiera. Los padres con baja sensibilidad así como los padres de niños con un temperamento difícil usaron el ICBC más frecuentemente. Los análisis de trayectoria muestran que el estrés de los padres no predijo el ICBC. Los resultados sugieren que el ICBC se ha convertido en parte de la tradición occidental de criar al niño.

Palabras claves: Ignorar el Llanto de los Niños a la Hora de Dormir, llanto controlado, sueño de los infantes, creencias culturales, estrés y sensibilidad de los padres

Special thanks to all parents for their participation. We also thank all students for assisting in the data collection. The study was run at the Department of Development and Education in Early Childhood, University of Konstanz, and was approved by the local ethics committee of the University of Konstanz. No external funding was secured for this study. Authors have no relevant financial relationships or conflicts of interest to disclose. Monique Maute conceived and designed the study and the data-collection instruments, coordinated data collection, and wrote and approved the manuscript as submitted. Sonja Perren critically supervised the study and revised the manuscript, and approved the final manuscript as submitted. Both authors agree to be accountable for all aspects of the work.

Direct correspondence to: Monique Maute, University of Konstanz, Department of Development and Education in Early Childhood, Universitätsstrasse 10, Konstanz BW, 78457 Germany; e-mail: monique.orzechowski@uni-konstanz.de. 
RÉSUMÉ: Le fait d'Ignorer les Pleurs des Enfants au Moment de Se Coucher (on abrège ici selon l'anglais ICBC) est un problème qui polarise les parents ainsi que les pédiatres. Bien que la plupart des études se concentrent sur l'efficacité des interventions du sommeil, aucune étude ne s'est jusqu'à présent interrogée sur les parents qui utilisent l'ICBC. Les parents trouvent souvent que les difficultés du sommeil des enfants sont très difficiles, mais des facteurs tels que l'influence d'approches occidentales sur le soin de l'enfant, le stress et la sensibilité n'ont pas été analysés en terme de ICBC. Un échantillon de 586 parents a rempli un questionnaire afin d'établir les relations entre les facteurs parentaux et la méthode d'ICBC. Les données ont été analysées en utilisant des modèles d'équations structurelles. Des variables latentes ont été utilisés pour mesurer le stress parental (l'Echelle de Stress Parental), la sensibilité (Questionnaire Situation-Réaction), les croyances parentales occidentales (Rigidité) et le tempérament des enfants (Index de Stress de Parentage). L'ICBC a été utilisé par 32,6\% $(\mathrm{n}=191)$ des parents dans cette étude. Les croyances occidentales des parents ont prédit l'ICBC. Des attitudes telles que le fait de nourrir l'enfant à heure fixe et de ne pas le porter afin de prévenir la dépendance étaient liées au fait de laisser l'enfant pleurer pour s'endormir. Des parents à faible sensibilité ainsi que les parents d'enfant ayant un tempérament difficile ont utilisé l'ICBC plus fréquemment. Une analyse causale montre que le stress parental n'a pas prédit l'ICBC. Les résultats suggèrent que l'ICBC fait partie de la tradition occidentale pour élever les enfants.

Mots clés: Ignorer les Pleurs des Enfants au Moment de Se Coucher, Pleurs Contrôlés, Sommeil des Bébés, Croyances Culturelles, Stress Parental et Sensibilité Parentale

ZUSAMMENFASSUNG: Das Ignorieren des kindlichen Weinens beim Einschlafen (ICBC) ist ein Thema, das Eltern und Kinderärzte polarisiert. Während sich die meisten Studien auf die Wirksamkeit von Schlafinterventionen konzentrieren, hat sich noch keine Studie der Frage gewidmet, welche Eltern das ICBC verwenden. Eltern empfinden die Schlafprobleme von Kindern oft als sehr herausfordernd, aber solche Faktoren wie der Einfluss westlicher Ansätze auf Säuglingsfürsorge, Stress und Sensitivität wurden im Sinne des ICBC noch nicht analysiert. Eine Stichprobe von 586 Eltern füllte einen Fragebogen aus, um die Beziehungen zwischen elterlichen Faktoren und der ICBC-Methode zu untersuchen. Die Daten wurden mithilfe von Strukturgleichungsmodellen analysiert. Latente Variablen wurden zur Messung von elterlichem Stress (,Parental Stress Scale“), elterlicher Sensitivität (,,Situation-Reaction-Questionnaire”), westlich orientierten elterlichen Überzeugungen (Rigidität) und kindlichem Temperament (,Parenting Stress Index“) verwendet. Das ICBC wurde von 32.6\% $(n=191)$ der Eltern dieser Studie verwendet. Die westlich orientierten Überzeugungen der Eltern sagten das ICBC vorher. Einstellungen wie das Füttern des Kindes nach Zeitplan und das Nicht-Tragen, um Abhängigkeiten zu vermeiden, wurden mit dem Weinen des Kindes beim Einschlafen in Verbindung gebracht. Eltern mit geringen Sensitivitätswerten sowie Eltern von Kindern mit schwierigem Temperament verwendeten das ICBC häufiger. Die Pfadanalyse zeigt, dass der elterliche Stress das ICBC nicht vorhersagte. Die Ergebnisse deuten darauf hin, dass das ICBC Teil der westlichen Erziehungstradition geworden ist.

Stichwörter: Ignorieren des kindlichen Weinens beim Einschlafen, kontrolliertes Weinen, Schlaf von Säuglingen, kulturelle Überzeugungen, elterlicher Stress und Sensitivität

抄録: 子どもが就寝時に泣くのを無視すること Ignoring Children’s Bedtime Crying (ICBC) は、親ばかりでなく小児科医も対立させる問 題である。多くの研究が睡眠介入の有効性に焦点づける一方、どちらの親が ICBCを用いるかに疑問を持った研究はまだない。親はし ばしば子どもの睡眠の難しさをとても困難な問題と感じているが、乳児のケアへの西洋的アプローチの影響、ストレスと感受性のよ うな要因については、ICBC の観点からはまだ分析されていない。586人の親が、親の要因と ICBCの方法との間の関係を調查する質 問紙に回答した。データは構造方程式モデリングを用いて分析された。潜在的変数が、親のストレス(親のストレス尺度 Parental Stress Scale)、感受性(状況一反応質問紙 Situation-Reaction-Questionnaire)、西洋志向の親の信念(硬直性 Rigidity)、および子どもの気質(育児 ストレス指標 Parenting Stress Index) を測定するために使われた。ICBC はこの研究の親の $32.6 \%(\mathrm{n}=191)$ に使われた。親の西洋志向の 信念は、ICBC を予測した。依存を予防するために子どもを時間通りに授乳し持ち越さないことのような態度は、子どもを寝るまで泣 かせておくことに関連した。感受性が低い親、ならびに困難な気質の乳児の親は ICBC をより頻繁に用いた。パス解析から、親のスト レスはICBC を予測しないことがわかる。結果から ICBC は西洋的育児の伝統の一部になっていることが示唆される。

キーワード：子どもが就寝時に泣くのを無視すること, コントロールされた泣き, 乳児の睡眠, 文化的信念, 親のストレスと感受性

摘要: 忽視兒童的睡前哭泣 (ICBC) 是一個使父母和兒科醫生極化的問題。儘管大多數研究都集中在睡眠干預的有效性上,但還沒有研究查 考那些家長使用 ICBC。父母經常發覺兒童的睡眠問題非常具有挑戰性, 但是西方的嬰兒護理方法、壓力和敏感性等影響因素尚未從 ICBC 的角度進行分析。586 名家長樣本完成問卷, 調查父母因素與 ICBC 方法的關係。數據使用結構方程模型分析。潛在變量用於測量父母壓 力 (父母壓力量表) 、敏感性 (情境 - 反應 - 問卷) 、西方導向的父母信念 (死板) 和兒童氣質 (育兒壓力指數)。在這項研究中, 32.6\% ( $\mathrm{n}=$ $191)$ 的父母使用 ICBC。父母的西方導向信念預測 ICBC。例如按照時間餵養孩子, 而不是為了防止依賴與讓孩子哭鬧人睡有關。低敏感 的父母以及性格困難兒童的父母更頻繁地使用 ICBC。路徑分析顯示父母壓力並不能預測 ICBC。結果表明 ICBC 已成為西方育兒傳統的 一部分。

關鍵詞：忽視兒童睡前哭鬧, 受控哭泣, 嬰兒睡覺, 文化信念, 父母壓力和敏感度 


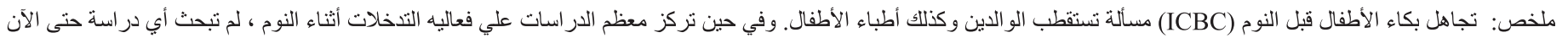



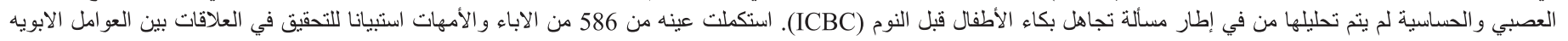

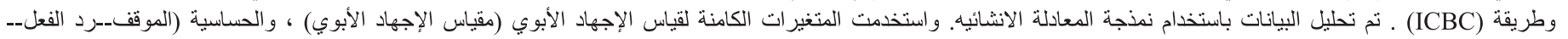



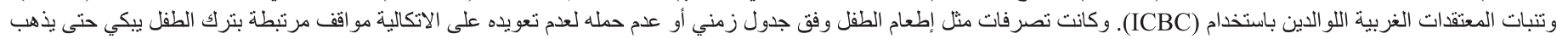



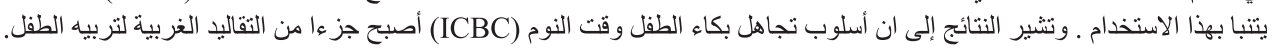
الكلمات الرئيسية: تجاهل بكاء الأطفال وقت النوم - مر اقبه البكاء ـ نوم الرضع ـ المعتقدات الثقافيةـ الإجهاد الأبوي والحساسية

Infants' crying is a highly stressful situation for parents (Beebe, Casey, \& Pinto-Martin, 1993). Especially at bedtime, parents often feel helpless if children cry constantly and are unable to fall asleep by themselves. This helplessness or uncertainty can often be exacerbated by conflicting advice received from friends, family members, and pediatricians, which may leave parents confused about whether to act instinctively or to follow the suggested practices. These struggles with children's sleep are the main reasons for seeking help and searching for further solutions in parenting advice books (Ferber, 1985; Ramos \& Youngclarke, 2006).

An effective way to reduce these symptoms is a behaviororiented sleep intervention such as "graduated extinction," also known as "controlled crying" and "sleep training" (Ferber, 1985; Kast-Zahn \& Morgenroth, 2011; Mindell, Kuhn, Lewin, Meltzer, \& Sadeh, 2006). In the current study, we use the term ignoring children's bedtime crying (ICBC) to include the kinds of sleep interventions where parents took the conscious decision to let their children cry to fall asleep, regardless of the fact that parents were aware that they had applied a behavior-oriented sleep intervention such as graduated extinction.

Graduated extinction instructs parents to partially ignore an infant's crying while trying to fall asleep and to check occasionally on the infant's well-being according to a defined time schedule (Ferber, 1985; Minde et al., 1993; Mindell et al., 2006). Sleep interventions are criticized by some infant mental health experts (Middlemiss, Granger, Goldberg, \& Nathans, 2012; Murray \& Ramchandani, 2007), but are very popular among parents, probably as a result of the frequently reported effectiveness of these interventions (Mindell et al., 2006). Behavioral treatments such as unmodified and graduated extinction reduce bedtime problems, at least for a certain period of time (Mindell et al., 2006).

This might be the reason why many parents use ICBC outside clinical settings on their own (Loutzenhiser, Hoffman, \& Beatch, 2014). In a survey of 411 Canadian parents, almost half of them reported using ICBC. Most of them used ICBC before their infants reached 6 months (Loutzenhiser et al., 2014). Even though this is not recommended for very young infants, its popularity is growing. In the United States, $61 \%$ of parenting advice books about children's sleep endorse "crying it out" with scheduled checking (Ramos \& Youngclarke, 2006). It is obvious that early infant care recommendations and the popularity of sleep books such as Solve Your Children's Sleep Problems (Ferber, 1985) have been shaping parenting practices.

Many theorists have raised concerns about causing stress to infants who do not experience maternal promptness in attending to their needs (Bell \& Ainsworth, 1972; Liedloff, 1985). In contrast, mothers who were emotionally available at bedtime played an important role in buffering infants' distress (Philbrook, Hozella, Kim, Jian, Shimizu \& Teti, 2014). These mothers were aware of infant cues and responded adequately to an infant's needs. Infants of these sensitive mothers showed less nighttime awakenings and more often slept through the night (Philbrook \& Teti, 2016). In addition to the concerns about causing stress by the method of ICBC, there has been limited research addressing long-term effects of sleep interventions.

This, combined with the critical debate on infants' health development (Murray \& Ramchandani, 2007), suggests a need to examine the underlying factors in the use of ICBC. The question therefore arises about whether ICBC is used as an emergency program to reduce parental stress and tiredness or whether it is unnecessarily widespread and used by parents because children's behavior does not conform to Western-oriented expectations of independence.

Parental expectations and beliefs are relevant to their parenting behavior. Traditions that have been passed from one generation to the next might be more relevant for carrying out sleep intervention, especially where previous infant care recommendations have encouraged parents not to soothe their baby's crying when falling asleep or at night (Ferber, 1985; Haarer, 1934). Independency and self-assertiveness are highly valued socialization goals in Western societies (Keller, Borke, Yovsi, Lohaus, \& Jensen, 2005; Keller, Völker, \& Yovsi, 2005; Valentin, 2005). These goals are visible in Western-oriented infant care, such as feeding a baby on a time schedule, putting a baby in a stroller rather than carrying it, or encouraging independent sleeping rather than co-sleeping (Bensel, 2002; Keller, Völker, \& Yovsi, 2005). Some experts have mentioned their concerns about these Western approaches to infant care as not satisfying specific infant needs (Schön \& Silvén, 2007). One recent study found that the absence of bed-sharing predicted less secure attachment (Mileva-Seitz et al., 2016), and less 
proximal care (e.g., shorter duration of breast-feeding and less body contact in infancy) has been associated with greater infant crying (St James-Roberts, 2006).

However, high parental expectations have often been reported in the context of children's sleep behavior in Western societies (Jenni, 2005; Lozoff, Askew, \& Wolf, 1996; Morelli, Rogoff, Oppenheim, \& Goldsmith, 1992; Valentin, 2005). For example, most parents do not wish to accompany their children while they fall asleep. Most parents favor objects such as a blanket or doll to help their infants to feel safe and to replace parental presence. Valentin (2005) found that only 1 in 5 parents sat with the child while he or she fell asleep, and he mentioned that the German ideal is to raise independent children who do not call for their parents at night. But this parenting style often does not respond adequately to the infant's immediate needs. In contrast to this, it is obvious that parents who are in doubt about their own role may be displaying more inconsistent parenting behavior at nighttime. Unclear expectations and problems with parent-infant bedtime interactions often cause more sleep disorders in young children (Sadeh \& Anders, 1993). This could help to explain why the parents' presence at bedtime, as the child is falling asleep, could reinforce an infant's nighttime awakenings and hinder sleep (Adair, Bauchner, Philipp, Levenson, \& Zuckerman, 1991). An optimal way to prevent sleep disorders seems to be a combination of high maternal emotional support (i.e., answering an infant's needs immediately) and the avoidance of bedtime activities such as tickling the child before sleep or holding the child during the transition to sleep (Philbrook \& Teti, 2016). Setting limits as well as giving the child enough proximity and support at bedtime is like trying to balance the expectations of Western culture with parents' natural instincts.

Western practice might be more parent-oriented than childoriented and might drive parents away from their own parenting instincts. Researchers from a more cultural perspective have noted the influence of Western cultures on children's sleep behavior and the interplay between culture and biology (Jenni, 2005; Keller, Völker, \& Yovsi, 2005; McKenna \& McDade, 2005; Valentin, 2005). It has never been clarified whether the high reported level of ICBC is a reflection of the parents' Western cultural beliefs about infant care; these parents might be raising their children to be more independent.

In the cultural and critical debate about ICBC, sleep interventions also are justified in terms of preventing child abuse and reducing parental stress, depression, and tiredness (Gradisar et al., 2016; Mindell et al., 2006), but solid factors explaining the widespread use of ICBC are still lacking. One reason might be grounded in the stress of being a parent. Parental stress relating to children's sleep behavior has always been of interest (Eckerberg, 2004; Meltzer \& Mindell, 2007). Rating children's sleep behavior as problematic has been associated with a higher parental stress load (Sinai \& Tikotzky, 2012). Maternal stress also was affected by the quality of maternal sleep, which in turn was predicted by toddlers' sleep behavior (Meltzer \& Mindell, 2007). If parental stress is understood as a consequence of increased demands on parenting, we can expect it to predict the implementation of ICBC.
However, crying is the most effective signal for parents to provide caregiving and activating the attachment system. Persistent infant crying in the early days explains why many parents report difficulties in carrying out the ICBC method (Johnson, 1991; Loutzenhiser et al., 2014) or why parents even stop after the first attempt. The biological instinct activates hormones such as dopamine and oxytocin, driving parents to promptly respond to infants' needs and reducing the risk of ignoring children's demands (Oe, 2004; Riem et al., 2011; Swain, Lorberbaum, Kose, \& Strathearn, 2007). However, acting promptly and adequately to children's needs in a way that reflects the construct of sensitivity would not be appropriate for ICBC. This raises the question of whether sensitive parents apply ICBC less frequently.

In addition to these parental factors, which may influence the use of ICBC, we should not underestimate the role that each individual child's temperament can play. The role of children's temperament in children's sleep behavior has been thoroughly investigated (Carey, 1974; Keener, Zeanah, \& Anders, 1988; Owens-Stively et al., 1997). Research mostly has found that a child with a more "difficult" temperament, with hyperactivity and lower adaptability, and who is more demanding has been associated with nighttime disturbances (Sadeh, Lavie, \& Scher, 1994; Thunström, 2002) as well as with poorer caregiving and family function (Sung, Hiscock, Sciberras, \& Efron, 2008). In contrast, more adaptability and a positive mood is associated with positive sleep behavior such as longer sleep duration (Weissbluth, 1984). Consequently, it can be suggested that a difficult child (Bates, Freeland, \& Lounsbury, 1979; Guerin, Gottfried, \& Thomas, 1997) is at greater risk of experiencing ICBC.

Although research cannot clearly say whether ICBC has long-term consequences for an infant's mental health, it could be assumed that offering no response to a baby's cry, as with ICBC, might actually harm a child. The child could stop crying, but a noncrying child also can experience psychological and physiological stress, as has been demonstrated in squirrel monkeys who changed their behavior independently of their physiological arousal (Coe, Glass, Wiener, \& Levine, 1983), as well as in humans (Middlemiss et al., 2012). It also has been shown that answering infants' crying within the first minute and adequate maternal responsiveness at bedtime are associated with lower infant cortisol levels across the night (Philbrook et al., 2014). Therefore, parental presence and emotional availability at bedtime should not be underestimated.

Therefore, reasons are required to explain the use of ICBC, and these will be investigated in this study. We hypothesize that ICBC is more frequently used by parents with Western-oriented parental beliefs and with high levels of stress. Furthermore, we investigate whether the use of ICBC is predicted by low parental sensitivity and a difficult child temperament.

\section{METHOD}

\section{Participants}

Participants were 586 Swiss and German parents with children between zero and 4 years old, who participated in an online survey. 
Parents of multiple children completed the questionnaire for their youngest child. The study link was published on the Web sites of different German and Swiss parenting magazines. Some parents who participated answered an advertisement in a local newspaper.

\section{Procedure}

The survey included questions on ICBC, parental factors, and attitudes toward infant handling. Detailed questions about sociodemographic characteristics were collected as well. Parents were informed about the study goals and rights of participation. The incentive was entry into a raffle for a chance to win one of $50 \mathrm{gift}$ vouchers worth 30 euros each. Parents under the age of 18 were not allowed to participate.

\section{Instruments}

Ignoring children's bedtime crying. ICBC was measured by the question "Did you ever intentionally let your child cry, in order to teach her/him to fall asleep by herself/himself?" with the response options of "yes," "somewhat yes," "somewhat no," and "no." All response options were grouped into two categories. The group with ICBC had responded with "yes" and "somewhat yes." Parents who let their child cry, but stayed with the child or held him or her during the transition to sleep, were excluded from the analysis. The group without ICBC responded to this question with "no" and "somewhat no." Other sleep interventions such as special forms of graduated extinction such as camping out methods or positive routines involving bedtime fading were excluded from the analysis.

To evaluate convergent validity of this measure, in a further question we evaluated sleep training based on the definition of graduated extinction (Ferber, 1985). Parents were asked if they ever carried out a sleep intervention and how they carried it out. This was defined as checking occasionally on the child's needs and leaving the room, even if the child was still crying. The point biserial correlation coefficient of ICBC and graduated extinction was $r_{\mathrm{pb}}=.945, p<.001$, which strongly supports the construct of ICBC.

Parental beliefs. Western-oriented parental cultural beliefs were assessed using two scales: feeding and carrying a baby. The scale of feeding is based on the subscale rigidity of the Questionnaire for the Investigation of Maternal Attitudes for Mothers of Infants and Toddlers (EMKK; Codreanu \& Engfer, 1984). It includes expectations about responding to children's needs in relation to feeding, such as "Even if the child cries, I stick to my time schedules for eating." We developed items to assess beliefs about carrying based on theoretical argumentations (e.g., a baby becomes spoiled if it is constantly carried) (Bensel, 2002; Keller, Völker, \& Yovsi, 2005). All items are rated on a Likert scale from 0 (strongly disagree) to 3 (strongly agree). High scores indicate parents' Western-oriented socialization goals in term of feeding and carrying a child such as less body contact or feeding on a time schedule.

Latent variables were identified using confirmatory factor analysis (CFA) and item reduction technique. Three items were retained for both the factors Feeding and Carrying, $\chi^{2}(d f=7)=$ 12.162, $p=.095$; Comparative Fit Index $(\mathrm{CFI})=.994$, Root Mean Square Error of Approximation (RMSEA) $=.036$, p of Close Fit $($ Pclose $)=.732$, Chi-square/Degrees of freedom $(\mathrm{CMIN} / \mathrm{DF})=$ 1.737 , which in turn represents the second-order factor WesternOriented Parental Beliefs.

Parental stress. Parental stress was assessed using the German version of the Parental Stress Scale (PSS; Berry \& Jones, 1995, Kölch \& Schmid, 2008). It measures perceived parental stress such as "The major source of stress in my life is my child(ren)." Items also are rated on a Likert scale from 1 (strongly disagree) to 5 (strongly agree). High stress scores can be interpreted as a high level of stress generated by parenthood, such as high demands on parental resources, parental restrictions, or children's behavior. The CFA, $\chi^{2}(d f=2)=1.280, p=.527$; CFI = 1.000, RMSEA $=.000$, Pclose $=.837, \mathrm{CMIN} / \mathrm{DF}=.640$, showed that the latent variable parental stress is best represented by four items.

Parental sensitivity. Parental sensitivity was investigated using one situation vignette of the Situation-Reaction-Questionnaire measuring parental sensitivity (PS-SRQ; Hänggi, Schweinberger, Gugger, $\&$ Perrez, 2010). For this study, we used the following vignette: "You are very busy with something that needs to be done urgently. Just a few seconds ago you looked after your child, but now your child is loudly drawing attention to itself." Parents rated their behavior-oriented response reaction toward their children's needs on a Likert scale from 1 (never) to 5 (always). High scores indicate high sensitivity. CFA, $\chi^{2}(d f=2)=1.742, p=.419$; CFI $=1.000$, RMSEA $=.000$, Pclose $=.776$, CMIN/DF $=.871$, showed that the latent variable parental sensitivity is best represented by four items.

Child temperament. Children's temperament was rated by parents using the Parenting Stress Index (Tröster \& Abidin, 2011), which focuses on characteristics of children's mood and adaption, such as "My child becomes upset even by small things." Items were rated on a Likert scale from 1 (strongly disagree) to 5 (strongly agree). High scores reflect a difficult child. CFA, $\chi^{2}(d f=2)=.068, p=$ .966 ; $\mathrm{CFI}=1.000, \mathrm{RMSEA}=.000$, Pclose $=.992, \mathrm{CMIN} / \mathrm{DF}=$ .034 , showed that the latent variable difficult temperament is best represented by four items.

Measurement model. CFA was conducted to determine whether the latent factors existed, and if path analysis was appropriate. Construct validity was first tested through univariate analyses. This step also was used for item reduction. The main goodness-of-fit indicators were calculated according to different experts (Chen, 2007; Cheung \& Rensvold, 2002). All univariate analyses for latent variables showed a good model fit.

In the second step, CFA was calculated for all variables in one model. All latent factors were allowed to covary. For this calculation, we used maximum likelihood estimation $(N=586)$. 


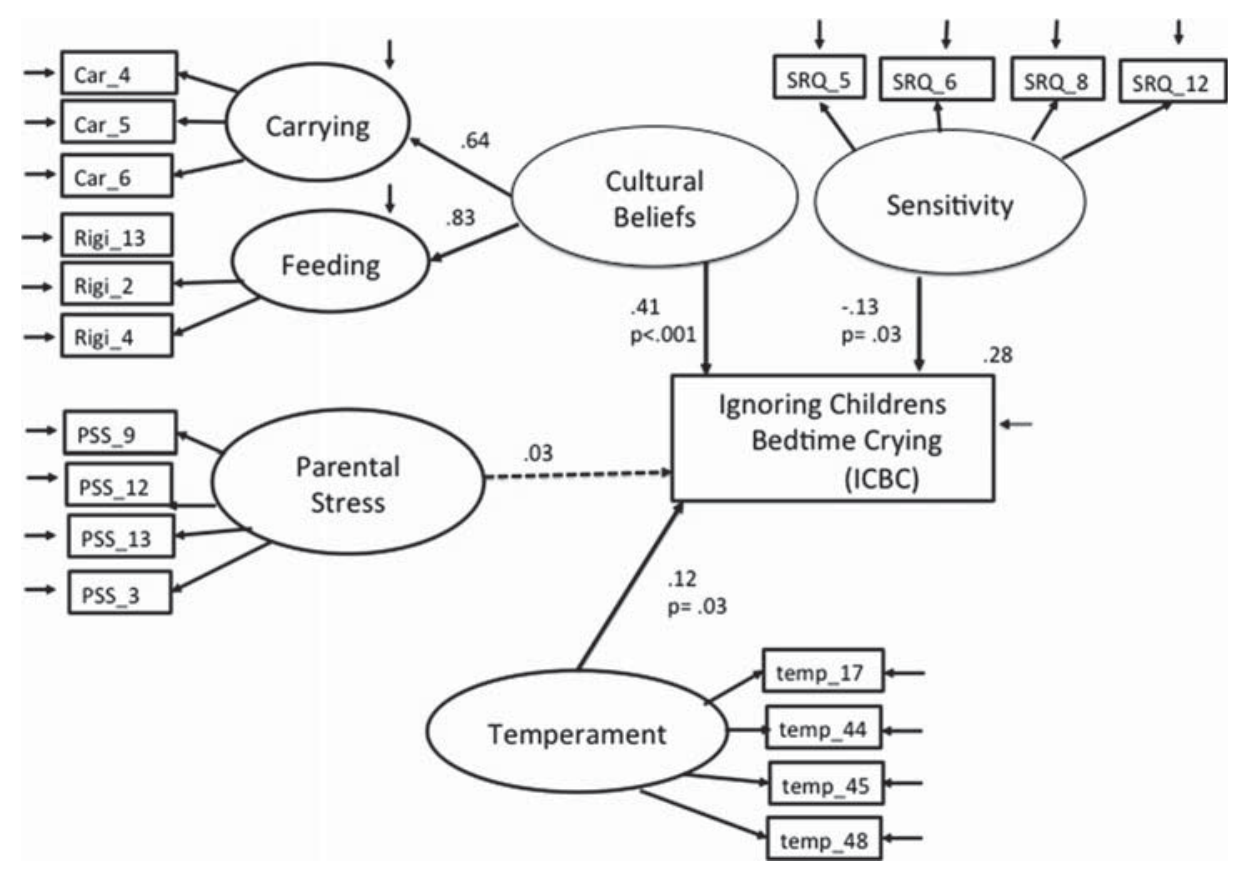

FIGURE 1. Path analysis showing significant main effects on ignoring children's bedtime crying (ICBC).

The final CFA showed a very good fit to the data, $\chi^{2}(\mathrm{df}=124)$ $=227.269, \mathrm{p}=.000 ; \mathrm{CFI}=.969, \mathrm{RMSEA}=.038$, Pclose $=.996$, $\mathrm{CMIN} / \mathrm{DF}=1,833$.

Furthermore, we built a path model to assess the influence of predictor variables to the dependent variable (ICBC) (Figure 1). All hypothesized paths and covariances were included in the model, and all latent variables were allowed to covary. Our model (Figure 1) with five values showed a very good fit to the data, $\chi^{2}(d f$ $=140)=271,209, p=.000, \mathrm{CFI}=.962$, RMSEA $=.040$, Pclose $=.990 \times 2 / \mathrm{DF}=1.937$.

\section{Data Analysis}

Analyses were performed in SPSS Version 23.0 and AMOS Version 23.0. For sample descriptions, ICBC was clustered into two main categories: one group without ICBC $(1=$ no, $2=$ somewhat $n o)$ and one with $\operatorname{ICBC}(3=$ somewhat yes, $4=y e s)$. The $\chi^{2}$ test was used to analyze differences in sample characteristics across the two groups of ICBC. Percentages were reported for each category. Correlations were calculated to report associations between ICBC and all variables of interest.

\section{RESULTS}

\section{Demographic Characteristics of Participants}

Sample characteristics by ICBC are shown in Table 1. A majority $(96.8 \%)$ of the responding parents were mothers. The response rate of parents from Germany was $15.5 \%$ for the group with ICBC, as compared to the $16.0 \%$ of parents from Switzerland and $1.0 \%$ of parents from other cultures. Children's gender was nearly equally distributed in the group with ICBC, with $51.3 \%$ girls and $48.7 \%$ boys. Employed parents tended to be more likely to use the ICBC method. Furthermore, there was increasing probability for children to have experienced ICBC as their age increased. No other significant group differences were found for sample characteristics.

\section{Bivariate Associations}

Intercorrelations between scales and subscales are shown in Table 2. All variables of interest were significantly associated with ICBC.

Parents' Western-oriented beliefs were positively associated with the use of ICBC. Therefore, parents who support statements such as feeding a child on a time schedule even if the child cries and who believe that constantly carrying an infant leads to clingy behavior showed increased use of ICBC. Parents' Western-oriented beliefs were the strongest association with ICBC. Furthermore, higher parental stress and a difficult child temperament in terms of mood and adaption were related to a higher use of ICBC. Negative association was found between parental sensitivity and ICBC, which demonstrates that promptness of response and attention toward the child decrease when parents highly endorsed the use of ICBC. In addition to sensitivity and temperament, all the main variables also related to each other.

\section{Path Analysis}

The path analysis showed a strong significant effect of parental cultural beliefs on ICBC, $\beta=0.41, p<.001$, which means that 
TABLE 1. Sample Characteristics by Ignoring Children's Bedtime Crying (ICBC)

\begin{tabular}{|c|c|c|c|}
\hline & $\begin{array}{c}\text { Group With ICBC } \\
32.6(n=191)\end{array}$ & $\begin{array}{c}\text { Group Without ICBC } \\
67.4(n=395)\end{array}$ & $p$ \\
\hline$\%$ Parents & & & .162 \\
\hline Mothers & 95.3 & 97.5 & \\
\hline Fathers & 4.7 & 2.5 & \\
\hline Age of Parents, $M(S D)$ & $32.3(4.7)$ & $33.2(5.4)$ & .262 \\
\hline$\%$ Parents' Education & & & .460 \\
\hline College/University Degree & 35.1 & 38.8 & \\
\hline Apprenticeship & 43.1 & 35.3 & \\
\hline School Leaving Certificate & 21.8 & 25.9 & \\
\hline \% Parents' Employment & & & $.004^{\mathrm{a}}$ \\
\hline Yes & 71.1 & 58.6 & \\
\hline \%No. of Children Per Family & & & .128 \\
\hline 1 & 57.1 & 48.4 & \\
\hline $2-3$ & 41.3 & 49.1 & \\
\hline$\geq 4$ & 1.6 & 2.5 & \\
\hline \%Child Gender & & & .743 \\
\hline Boys & 48.7 & 49.9 & \\
\hline$\%$ Child Age & & & $.006^{\mathrm{a}}$ \\
\hline 0-6 Months & 7.9 & 18.6. & \\
\hline 7-12 Months & 17.8 & 17.8 & \\
\hline 13-24 Months & 32.5 & 29.8 & \\
\hline$>2$ Years & 41.9 & 33.8 & \\
\hline
\end{tabular}

Note. Values are frequencies (\%) for categorical classifications of either a group with ICBC or without ICBC. $N=586$.

${ }^{\mathrm{a}} p<.05$.

TABLE 2. Bivariate Correlations of Latent Factors

\begin{tabular}{lccccc}
\hline & 1 & 2 & 3 & 4 & 5 \\
\hline ICBC & - & $.50^{* * *}$ & $.17^{* * *}$ & $-.33^{* * *}$ & $.20^{* * * *}$ \\
Western Beliefs & & - & $.16^{* *}$ & $-.47^{* * *}$ & $.16^{* *}$ \\
Parental Stress & & & - & $-.11^{*}$ & $.47^{* * *}$ \\
Sensitivity & & & & - & -.23 \\
Difficult Temperament & & & & & -
\end{tabular}

$N=586$. ICBC $=$ ignoring children's bedtime crying.

${ }^{*} p \leq .05 .{ }^{* *} p \leq .01 .{ }^{* * *} p \leq .001$.

the more pronounced their Western-oriented beliefs, the more parents were likely to use ICBC. Parental stress no longer predicted ICBC. Parental sensitivity, $\beta=-0.13, p<.05$, and children's temperament, $\beta=0.12, p<.05$, predicted the use of ICBC as well. The less sensitive parents are, the more they use ICBC; and the more difficult the children have been rated in terms of adaptation and mood, the higher the use of ICBC. The variance for ICBC explained by all exogenous variables is $28 \%$.

\section{DISCUSSION}

This study reports data from 586 parents and investigated predictors for the use of ICBC. The reporting of ICBC in this study is
$32.6 \%$ of the sample, which is less widespread than in past research (Loutzenhiser et al., 2014), but still highly prevalent, which suggests that ICBC is more widespread in North America than in Germany and Switzerland; differences also might be explained by disparate methodology.

The primary aim of this study was to find out whether parents use ICBC because of Western-oriented beliefs about handling their infants or as a result of their parental stress. Our data indicate that it is mainly parents with Western-oriented cultural beliefs about infant handling, and with a focus on independence, who use ICBC. Against our expectations, ICBC was not related to parental stress.

Explaining the main effect of parents' cultural beliefs on ICBC leads us to the importance of parental approaches to children's independence in Western cultures (Keller, Borke et al., 2005; Keller, Völker, \& Yovsi, 2005; Valentin, 2005). This is visible in the belief that constantly carrying an infant will spoil the child and can lead to clingy behavior, and the enforcement of fixed feeding times even when the infant cries. Western parents also often desire solitary sleep (Valentin, 2005), which might drive parents to struggle more because falling asleep alone is not necessarily adapted to the biology of an infant (Jenni, 2005) or to an infant's physical needs (Schön \& Silvén, 2007). Culture always has an impact on the assessment of children's sleep behavior and whether parents experience children's sleep difficulties as a problem. In a sample of co-slept families, parents' ratings of children's nighttime waking as problematic were based on cultural background (Lozoff et al., 1996). Furthermore, Japanese parents reported few concerns about insomnia, as compared to parents in the United States (Stearns, Rowland, \& Giarnella, 1996). In other parts of the world where parents practice co-sleeping, sleep disorders barely exist (Jenni, 2005; McKenna \& McDade, 2005; Morelli et al., 1992). Children's difficulties in falling asleep began to emerge as more of a problem in the industrialized Western world. ICBC therefore also might reflect infants' sleep environment in industrialized countries.

Positive effects have been reported to result from more natural ways of infant handling, such as co-sleeping, physical contact, frequent feeding, and carrying. These methods have been associated with lower rates of infant crying (Esposito et al., 2013; St JamesRoberts, 2006) as well as fewer bedtime struggles (Jenni, 2005; McKenna \& McDade, 2005; Morelli et al., 1992). ICBC might still be a solution for parents who are placed between cultural expectations and children's biology. This study can help to understand the unnecessarily widespread use of ICBC because parents' predominant Western approaches to infant care matter most and do not always conform to children's needs.

The fact that no effect was found from parental stress on the implementation of ICBC, except perhaps for correlations, may be due to this study's concentration on parental stress alone. This includes parents' major source of stress from their children and related personal restrictions. However, perceived stress or the stress of daily work might be more relevant for carrying out ICBC. This would explain why high numbers of employed parents tended to 
use ICBC in this study. Further studies should measure stress in other areas of life. The fact that parental stress was not a decisive factor for carrying out ICBC suggests that it is parental beliefs, influenced by the history of Western childrearing practices, which is the most relevant factor in the implementation of ICBC.

To our knowledge, this is the first study which found that parents using ICBC are less sensitive to their children. Although small effects were found in terms of sensitivity, this might be one of the main negative side effects of sleep interventions. Less sensitive parents might not see the cause of stress in their children, even when they suffer traumatically. Loutzenhiser et al. (2014) found in an Internet-based study of 411 Canadian parents, almost 50\% of whom used controlled crying techniques, that $27.5 \%$ of these parents had used ICBC more than five times (Loutzenhiser et al., 2014). It would be important to question which parents apply ICBC several times to their children and the extent to which sensitivity plays a role. Furthermore, Loutzenhiser et al. also reported that parents who did not assess ICBC as stressful for themselves also did not assess it as stressful for their children, and it was these parents who used controlled crying for longer periods. This study did not investigate whether these parents were less sensitive to their infants, but there is a suggestion that sensitive parents are unable to listen to the intense crying of their children for the length of time needed to establish the new sleep behavior. Sensitivity might play an important role in carrying out a sleep intervention. Difficulties in enduring a sleep intervention were reported in earlier research (Johnson, 1991; Rickert \& Johnson, 1988), but to our knowledge, no study has monitored parental sensitivity in this context. Blunden and Baills (2013) found that parents stopped controlled crying or reported not even starting an intervention because they could not stand the sound of crying or found it too stressful to hear their infant crying alone. In our study, we did not control for the length and persistence of using ICBC.

Furthermore, whether graduated sleep interventions such as ICBC also can lead to less sensitive behavior during daytime warrants further study. Perceived positive effects of ICBC, such as an increase in infants' total sleep, a reduction in nighttime waking, the ability to fall asleep on their own, or the advice received from an expert in infant health, could influence how parents think about and potentially respond to infant crying at other times. Habituation effects and a more blunted behavior pattern after long periods of nighttime crying might be plausible reasons for a reduction of parental sensitivity in general; very little research has examined such questions. Further research about prompt parenting behavior and sleep interventions also should be discussed in relation to children's age.

Further analysis revealed that a difficult child temperament predicted ICBC, but the effect was small and lower than expected in this study. Nevertheless, ICBC was applied more by parents whose child showed negative moods and had difficulties in adapting. Despite the associations between a difficult child's temperament and problems with sleep onset or sleep disturbances (Carey, 1974; Keener et al., 1988), the concept of differential susceptibility to ICBC has so far been less considered.
Differential susceptibility has been the subject of intensive research in recent years, and studies have found that parenting qualities such as sensitivity are important for a child's behavior when it has been classified as difficult, as compared to that of other children (Bradley \& Corwyn, 2008; Stright, Gallagher, \& Kelley, 2008). To examine whether highly irritable children suffer more intensive distress in ICBC, further studies therefore should address the influence of differential susceptibility regarding the use of ICBC and potential harms.

There may be differences between infants who at an early age experience long periods of crying, which is not adequately answered by parents, as compared to short crying bouts or grumbling in older children. The latter can help children develop regulation skills, and short grumbling can help children learn to self-soothe (Goldbeck, 2004).

Age might be the main concern in using ICBC because of children's developmental stages (e.g., object permanence, development of regulation competences, and separation anxiety). Sleep interventions also have benefits for parents' and children's sleep behavior (France, 1992; Gradisar et al., 2016; Hiscock, Bayer, Hampton, Ukoumunne, \& Wake, 2008; Mindell et al., 2006), and a recent randomized controlled study has shown that ICBC does not lead to emotional and behavioral problems or insecure attachment (Gradisar et al., 2016). However, the empirical evidence is still not adequate to conclude how long infants' crying can safely be ignored or to say which children do not suffer. Most of these studies have examined the effects of ICBC on children's emotional well-being on the basis of parents' assessments and mostly with only a few participants. It can be suggested that well-rested parents more positively rate their children. One systematic review found that research about behavioral sleep interventions in infancy often does not address other influence parameters or interaction effects when interpreting data (Douglas \& Hill, 2013). Instead, the authors argued that behavioral interventions can unintentionally provoke more crying or lead to premature termination of breast-feeding. There also was no evidence that sleep disorders at a later point in childhood could be prevented by using a behavioral sleep intervention in the first 6 months (Douglas \& Hill, 2013). This was confirmed by Price, Wake, Ukoumunne, and Hiscock (2012), who found that behavioral sleep techniques had no beneficial effects but also no disadvantages for children's sleep behavior in the longterm.

Further studies are urgently needed and should address the costs and harms of ICBC in relation to children's age, parental benefits, and the concept of differential susceptibility.

Viewing our findings as a whole, we can see that ICBC is widespread in Western cultures and not implemented solely by parents in need. As long as there is inadequate evidence about potential harms to children, and as long as ICBC is applied by less sensitive parents and because of Western-oriented beliefs, more research is needed before ICBC can be recommended beyond doubt.

One strength of this study is the relatively large sample, which might reflect parents' interests in the issue of children's sleep 
behavior. We suggest that we have reached parents who are more willing to share information about the use of ICBC in an online survey, where no interviewer can influence responses, and therefore reducing social desirability bias. Furthermore, this study focused on parents' intentional decision to let their children cry to teach them to fall asleep by themselves. In contrast to an early study (Loutzenhiser et al., 2014), we deliberately decided to give more response options to reach those parents who make the conscious decision to let the child cry to fall asleep, but have not followed through with implementation because they could not tolerate the crying or were interrupted because of child sickness. We suggested that these parents would not totally agree ("yes") with the use of ICBC but would tend to rate "somewhat yes" rather than "no" when they have the option of taking a position. The aim was to examine parents' use of ICBC independently of time span. The one-item measure to assess ICBC is comparable with early research (Blunden \& Baills, 2013; Loutzenhiser et al., 2014), and additionally, the construct of ICBC is strongly supported by the reported convergent validity.

This study also has some limitations. For example, it did not identify the first time that parents used ICBC, or the frequency and time span, because of parents' difficulties in reporting ICBC retrospectively over a time span of up to 4 years as well as the use of ICBC over various periods of time. The use of controlled crying over several weeks has been reported earlier (Loutzenhiser et al., 2014). Furthermore, note that this study did not control for the success of ICBC regarding parenting stress. There might be different results when monitoring the positive effects of ICBC. The stability of parental stress has been reported elsewhere (Crnic, Gaze, \& Hoffman, 2005; Lederberg \& Golbach, 2002; Paradise et al., 1999), and stress did not change in the long-term for a group with sleep intervention versus a control group without sleep intervention (Price et al., 2012). Parental sensitivity was assessed using one vignette of the Situation-Reaction Questionnaire, and focused only on the subscales of Promptness and Distraction. Regarding promptness, children's age should be examined, as we would assume that promptness might be more relevant in infancy than for children 3 or 4 years of age.

\section{Conclusions}

Parental expectations and beliefs matter most in the context of infants' sleep behavior, and this should be taken into account. The best-selling advice books and the popularity of sleep interventions such as ICBC might have contributed to legitimizing crying to fall asleep in Western cultures, and the influence of parents' belief system and instinctive behavior might be underestimated. Positive bedtime routines and parental presence also could be an effective solution (Mindell et al., 2006), and children might not suffer from high distress and anxiety as we assume they do in ICBC. Our results can help to understand the importance of culture and its impact on parents' beliefs about childrearing practices to date.

\section{REFERENCES}

Adair, R., Bauchner, H., Philipp, B., Levenson, S., \& Zuckerman, B. (1991). Night waking during infancy: Role of parental presence at bedtime. Pediatrics, 87(4), 500-504.

Bates, J.E., Freeland, C.A.B., \& Lounsbury, M.L. (1979). Measurement of infant difficultness. Child Development, 794-803. https://doi.org/10.2301/1128946

Beebe, S.A., Casey, R., \& Pinto-Martin, J. (1993). Association of reported infant crying and maternal parenting stress. Clinical Pediatrics, 32(1), 15-19. https://doi.org/10.1177/000992289303200103

Bell, S.M., \& Ainsworth, M.D.S. (1972). Infant crying and maternal responsiveness. Child Development, 43(4), 1171-1190.

Bensel, J. (2002). Stone age babies in the nuclear age - Effects of the missing fit between biological needs and neo cultural environments. Children's world: Anthropology- History-Cultural Comparison (pp. 25-40). Cologne: Böhlau.

Berry, J.O., \& Jones, W.H. (1995). The Parental Stress Scale: Initial psychometric evidence. Journal of Social and Personal Relationships, 12(3), 463-472. https://doi.org/10.1177/0265407595123009

Blunden, S., \& Baills, A. (2013). Treatment of behavioural sleep problems: Asking the parents. Sleep Disorders: Treatment and Care, 2(2), 1-7. https://doi.org/10.4172/2325-9639.1000110

Bradley, R.H., \& Corwyn, R.F. (2008). Infant temperament, parenting, and externalizing behavior in first grade: A test of the differential susceptibility hypothesis. Journal of Child Psychology and Psychiatry, 49(2), 124-131.

Carey, W.B. (1974). Night waking and temperament in infancy. Journal of Pediatrics, 84(5), 756-758. https://doi.org/10. 1016/S0022-3476(74)80027-2

Chen, F.F. (2007). Sensitivity of goodness of fit indexes to lack of measurement invariance. Structural Equation Modeling, 14(3), 464-504. https://doi.org/10.1080/10705510701301834

Cheung, G.W., \& Rensvold, R.B. (2002). Evaluating goodness-offit indexes for testing measurement invariance. Structural Equation Modeling, 9(2), 233-255. https://doi.org/10.1207/S1532800 7SEM0902_5

Codreanu, N., \& Engfer, A. (1984). Development and validation of the Questionnaire for the Investigation of Maternal Attitudes for Mothers of Infants and Toddlers (EMKK). Unpublished research report, University of Munich, Institute of Psychology.

Coe, C.L., Glass, J.C., Wiener, S.G., \& Levine, S. (1983). Behavioral, but not physiological, adaptation to repeated separation in mother and infant primates. Psychoneuroendocrinology, 8(4), 401409. https://doi.org/10.1016/0306-4530(83)90019-7

Crnic, K.A., Gaze, C., \& Hoffman, C. (2005). Cumulative parenting stress across the preschool period: Relations to maternal parenting and child behaviour at age 5. Infant and Child Development, 14(2), 117-132. https://doi.org/10.1002/icd.384

Douglas, P.S., \& Hill, P.S. (2013). Behavioral sleep interventions in the first six months of life do not improve outcomes for mothers or infants: A systematic review. Journal of Developmental \& Behavioral Pediatrics, 34(7), 497-507. https://doi.org/10.1097/DBP.0b013e31829 cafa6 
Eckerberg, B. (2004). Treatment of sleep problems in families with young children: Effects of treatment on family well-being. Acta Paediatrica, 93(1), 126-134. https://doi.org/10.1080/08035250310007754

Esposito, G., Yoshida, S., Ohnishi, R., Tsuneoka, Y., Rostagno, M. del C., Yokota, S. et al. (2013). Infant calming responses during maternal carrying in humans and mice. Current Biology, 23(9), 739-745. https://doi.org/10.1016/j.cub.2013.03.041

Ferber, R. (1985). Solve your child's sleep problems. New York: Simon $\&$ Schuster.

France, K.G. (1992). Behavior characteristics and security in sleepdisturbed infants treated with extinction. Journal of Pediatric Psychology, 17(4), 467-475. https://doi.org/10.1093/jpepsy/17.4. 467

Goldbeck, L. (2004). Papoušek, M., Schieche, M., \& Wurmser, H. (Eds.). (2004). Regulatory disorders in early childhood. Early risks and intervention in the developing parent-infant-relationship. Bern: Huber (Review). Practice of Child Psychology and Child Psychiatry, 53(10), 756-757.

Gradisar, M., Jackson, K., Spurrier, N.J., Gibson, J., Whitham, J., Williams, A.S. et al. (2016). Behavioral interventions for infant sleep problems: A randomized controlled trial. Pediatrics, e20151486. https://doi.org/10.1542/peds.2015-1486

Guerin, D.W., Gottfried, A.W., \& Thomas, C.W. (1997). Difficult temperament and behaviour problems: A longitudinal study from 1.5 to 12 years. International Journal of Behavioral Development, 21(1), 71-90. https://doi.org/10.1080/016502597384992

Haarer, J. (1934). The German mother and her first child. Munich: Carl Gerber Verlag.

Hänggi, Y., Schweinberger, K., Gugger, N., \& Perrez, M. (2010). Situation-reaction questionnaire measuring parental sensitivity (PS-SRQ). Journal of Developmental Psychology and Educational Psychology, 42(1), 1-14. https://doi.org/10.1026/0049-8637/ a000001

Hiscock, H., Bayer, J.K., Hampton, A., Ukoumunne, O.C., \& Wake, M. (2008). Long-term mother and child mental health effects of a population-based infant sleep intervention: Cluster-randomized, controlled trial. Pediatrics, 122(3), e621-e627. https://doi.org/ 10.1542/peds.2007-3783

Jenni, O.G. (2005). Children's sleep: An interplay between culture and biology. Pediatrics, 115(1), 204-216. https://doi.org/10.1542/peds. 2004-0815B

Johnson, C.M. (1991). Infant and toddler sleep: A telephone survey of parents in one community. Journal of Developmental and Behavioral Pediatrics, 12(2), 108-114.

Kast-Zahn, A., \& Morgenroth, H. (2011). Every child can learn to sleep. Gräfe und Unzer Verlag GmbH.

Keener, M.A., Zeanah, C.H., \& Anders, T.F. (1988). Infant temperament, sleep organization, and nighttime parental interventions. Pediatrics, 81(6), 762-771.

Keller, H., Borke, J., Yovsi, R., Lohaus, A., \& Jensen, H. (2005). Cultural orientations and historical changes as predictors of parenting behaviour. International Journal of Behavioral Development, 29(3), 229-237. https://doi.org/10.1177/01650250544000017
Kölch, M. \& Schmid, M. (2008). Parental stress and attitudes to youth welfare in parents with mental disorders. Practice of Child Psychologie and Child Psychiatry, 57, 774-788.

Keller, H., Völker, S., \& Yovsi, R.D. (2005). Conceptions of parenting in different cultural communities: The case of West African Nso and Northern German women. Social Development, 14(1), 158-180. https://doi.org/10.1111/j.1467-9507.2005.00295.x

Lederberg, A.R., \& Golbach, T. (2002). Parenting stress and social support in hearing mothers of deaf and hearing children: A longitudinal study. Journal of Deaf Studies and Deaf Education, 7(4), 330-345. https://doi.org/10.1093/deafed/7.4.330

Liedloff, J. (1985). The continuum concept: Allowing human nature to work successfully. Boston: Addison-Wesley Publishing Company.

Loutzenhiser, L., Hoffman, J., \& Beatch, J. (2014). Parental perceptions of the effectiveness of graduated extinction in reducing infant nightwakings. Journal of Reproductive and Infant Psychology Advance online publication. https://doi.org/10.1080/02646838.2014.910864

Lozoff, B., Askew, G.L., \& Wolf, A.W. (1996). Cosleeping and early childhood sleep problems: Effects of ethnicity and socioeconomic status. Journal of Developmental and Behavioral Pediatrics, 17(1), 9-15. https://doi.org/10.1097/00004703-199602000-00002

McKenna, J.J., \& McDade, T. (2005). Why babies should never sleep alone: A review of the co-sleeping controversy in relation to SIDS, bedsharing and breast feeding. Paediatric Respiratory Reviews, 6(2), 134-152. https://doi.org/10.1016/j.prrv.2005.03.006

Meltzer, L.J., \& Mindell, J.A. (2007). Relationship between child sleep disturbances and maternal sleep, mood, and parenting stress: A pilot study. Journal of Family Psychology, 21(1), 67-73. https://doi.org/10.1037/0893-3200.21.1.67

Middlemiss, W., Granger, D.A., Goldberg, W.A., \& Nathans, L. (2012). Asynchrony of mother-infant hypothalamic-pituitary-adrenal axis activity following extinction of infant crying responses induced during the transition to sleep. Early Human Development, 88(4), 227232. https://doi.org/10.1016/j.earlhumdev.2011.08.010

Mileva-Seitz, V.R., Luijk, M.P.C.M., van IJzendoorn, M.H., BakermansKranenburg, M.J., Jaddoe, V.W.V., Hofman, A. et al. (2016). Association between infant nighttime-sleep location and attachment security: No easy verdict. Infant Mental Health Journal, 37(1), 5-16. https://doi.org/10.1002/imhj.21547

Minde, K., Popiel, K., Leos, N., Falkner, S., Parker, K., \& Handleyâ€€"Derry, M. (1993). The evaluation and treatment of sleep disturbances in young children. Journal of Child Psychology and Psychiatry, 34(4), 521-533. https://doi.org/10.1111/j.1469 -7610.1993.tb01033.x

Mindell, J.A., Kuhn, B., Lewin, D.S., Meltzer, L.J., \& Sadeh, A. (2006). Behavioral treatment of bedtime problems and night wakings in infants and young children. Sleep, 29(10), 1263-1276.

Morelli, G.A., Rogoff, B., Oppenheim, D., \& Goldsmith, D. (1992). Cultural variation in infants' sleeping arrangements: Questions of independence. Developmental Psychology, 28(4), 604-613. https://doi.org/10.1037/0012-1649.28.4.604

Murray, L., \& Ramchandani, P. (2007). Might prevention be better than cure? Archives of Disease in Childhood, 92(11), 943-944. 
Oe, K. (2004). The signal functions of early infant crying. Behavioral and Brain Sciences, 27, 443-490.

Owens-Stively, J., Frank, N., Smith, A., Hagino, O., Spirito, A., Arrigan, M., \& Alario, A.J. (1997). Child temperament, parenting discipline style, and daytime behavior in childhood sleep disorders. Journal of Developmental \& Behavioral Pediatrics, 18(5), 314-321.

Paradise, J.L., Feldman, H.M., Colborn, D.K., Campbell, T.F., Dollaghan, C.A., Rockette, H.E. et al. (1999). Parental stress and parent-rated child behavior in relation to otitis media in the first three years of life. Pediatrics, 104(6), 1264-1273.

Philbrook, L.E., Hozella, A.C., Kim, B.R., Jian, N., Shimizu, M., \& Teti, D.M. (2014). Maternal emotional availability at bedtime and infant cortisol at 1 and 3 months. Early Human Development, 90(10), 595605. https://doi.org/10.1016/j.earlhumdev.2014.05.014

Philbrook, L.E., \& Teti, D.M. (2016). Bidirectional associations between bedtime parenting and infant sleep: Parenting quality, parenting practices, and their interaction. Journal of Family Psychology, 30(4), 431-441. https://doi.org/10.1037/fam0000198

Price, A.M., Wake, M., Ukoumunne, O.C., \& Hiscock, H. (2012). Five-year follow-up of harms and benefits of behavioral infant sleep intervention: Randomized trial. Pediatrics, 130(4), 643-651. https://doi.org/10.1542/peds.2011-3467

Ramos, K.D., \& Youngclarke, D.M. (2006). Parenting advice books about child sleep: Cosleeping and crying it out. Sleep, 29(12), 16161623 .

Rickert, V.I., \& Johnson, C.M. (1988). Reducing nocturnal awakening and crying episodes in infants and young children: A comparison between scheduled awakenings and systematic ignoring. Pediatrics, 81(2), 203-212.

Riem, M.M.E., Bakermans-Kranenburg, M.J., Pieper, S., Tops, M., Boksem, M.A.S., Vermeiren, R.R.J.M. et al. (2011). Oxytocin modulates amygdala, insula, and inferior frontal gyrus responses to infant crying: A randomized controlled trial. Biological Psychiatry, 70(3), 291-297. https://doi.org/10.1016/j.biopsych.2011.02.006

Sadeh, A., \& Anders, T.F. (1993). Infant sleep problems: Origins, assessment, interventions. Infant Mental Health Journal, 14(1), 17-34. https://doi.org/10.1002/1097-0355(199321)14:1<17

Sadeh, A., Lavie, P., \& Scher, A. (1994). Sleep and temperament: Maternal perceptions of temperament of sleep-disturbed toddlers. Early Education and Development, 5(4), 311-322. https://doi.org/ 10.1207/s15566935eed0504_6
Schön, R.A., \& Silvén, M. (2007). Natural parenting: Back to basics in infant care. Evolutionary Psychology, 5(1), 102-183. https://doi.org/10.1177/147470490700500110

Sinai, D., \& Tikotzky, L. (2012). Infant sleep, parental sleep and parenting stress in families of mothers on maternity leave and in families of working mothers. Infant Behavior \& Development, 35(2), 179-186. https://doi.org/10.1016/j.infbeh.2012.01.006

Stearns, P.N., Rowland, P., \& Giarnella, L. (1996). Children's sleep: Sketching historical change. Journal of Social History, 345-366. https://doi.org/10.1353/jsh/30.2.345

St James-Roberts, I. (2006). Infant crying and sleeping in London, Copenhagen and when parents adopt a "proximal" form of care. Pediatrics, 117(6), e1146-e1155. https://doi.org/10.1542/peds.20052387

Stright, A.D., Gallagher, K.C., \& Kelley, K. (2008). Infant temperament moderates relations between maternal parenting in early childhood and children's adjustment in first grade. Child Development, 79(1), 186-200. https://doi.org/10.1111/j.1467-8624.2007.01119.x

Sung, V., Hiscock, H., Sciberras, E., \& Efron, D. (2008). Sleep problems in children with attention-deficit/hyperactivity disorder: Prevalence and the effect on the child and family. Archives of Pediatrics \& Adolescent Medicine, 162(4), 336-342. https://doi.org/10. 1001/archpedi.162.4.336

Swain, J.E., Lorberbaum, J.P., Kose, S., \& Strathearn, L. (2007). Brain basis of early parent/infant interactions: Psychology, physiology, and in vivo functional neuroimaging studies. Journal of Child Psychology and Psychiatry, 48(3-4), 262-287. https://doi.org/10. 1111/j.1469-7610.2007.01731.x

Thunström, M. (2002). Severe sleep problems in infancy associated with subsequent development of attention-deficit/hyperactivity disorder at 5.5 years of age. Acta Paediatrica, 5, 27. https://doi.org/10.1111/j.1651-2227.2002.tb03281.x

Tröster, H., \& Abidin, R.R. (2011). Eltern-Belastungs-Inventar: EBI [German version of the Parenting Stress Index (PSI) (R.R. Abidin, Trans.)]. Gottingen, Germany: Hogrefe.

Valentin, S.R. (2005). Commentary: Sleep in German infantsThe "cult" of independence. Pediatrics, 115(1), 269-271. https://doi.org/10.1542/peds.2004-0815J

Weissbluth, M. (1984). Sleep duration, temperament, and Conners' ratings of three-year-old children. Journal of Developmental \& Behavioral Pediatrics, 5(3), 120-123. https://doi. org/10.1097/00004703-1984060000-00003 